\title{
Impact of Say on Pay on Executive Compensation of Firms Listed on the Toronto Stock Exchange
}

\author{
Sylvie Berthelot ${ }^{1}$, Vanessa Serret ${ }^{2}$, Jessica Sylvain ${ }^{1} \&$ Michel Coulmont ${ }^{1}$ \\ ${ }^{1}$ Université de Sherbrooke, Sherbrooke, Canada \\ ${ }^{2}$ Université de Bretagne-Sud, Vannes, France \\ Correspondence: Sylvie Berthelot, Faculté d'Administration, Université de Sherbrooke, 2500 bld. Université, \\ Sherbrooke, J1K 2R1, Canada. Tel: 1-819-821-8000 ext. 62003. E-mail: sylvie.berthelot@usherbrooke.ca
}

Received: October 8, 2015

Accepted: October 24, 2015

Online Published: November 25, 2015

doi:10.5539/ijbm.v10n12p40

URL: http://dx.doi.org/10.5539/ijbm.v10n12p40

\begin{abstract}
Unlike in a number of other countries, the United Kingdom and the United States being two examples, SoP is not prescribed by regulation in Canada. To contribute to the debate on the relevance of a regulation adapted to the Canadian context, this article measures the impact of Say on Pay in firms listed on the Toronto Stock Exchange that voluntarily adopted this practice. Based on a sample of 45 firms, the study results show that the adoption of SoP does not improve the pay-performance relationship or lead to lower executive total compensation. These findings therefore raise questions about the effectiveness of Say on Pay as a governance tool.
\end{abstract}

Keywords: compensation, managerial power, performance, say on pay

\section{Introduction}

Public and academic debates regularly address the issue of corporate executive compensation for a number of reasons. For instance, studies have shown that executive pay levels continue to rise (Murphy, 2012; Gabaix \& Landier, 2008; Gélinas \& Baillargeon, 2013; Craighead, Magnan, \& Thorne, 2004) and that such increases are not always performance-related (Bebchuk \& Fried, 2005). At the time of the financial crisis in 2007, public opinion as a whole considered executive compensation figures to be unacceptable because they were unrelated to firms' actual performance. As well, the escalation of top executives' pay has broadened the gap between their salaries and the lowest salary levels, which in turn raises social issues.

Traditionally, increases in executive pay have been determined by a firm's board of directors (the board). The board establishes a system of financial compensation that aligns executives' and shareholders' interests within the framework of an agency relationship characterized by conflicting objectives (Jensen \& Meckling, 1976). Given the dramatic rise in compensation noted, boards and their directors are suspected of being too passive vis-à-vis their CEOs, to the detriment of their shareholders (Bebchuk \& Fried, 2005). In the 2000s, these misgivings led to the introduction of a new governance tool, Say on Pay (SoP), granting shareholders the right to express their support (or non-support) for the compensation policy proposed by the board at the annual general meeting (AGM). SoP should therefore be seen as a substitute mechanism for the board (Thomas, Palmiter \& Cotter, 2012) that limits compensation and reduces agency costs. In 2002, the United Kingdom was the first country to impose SoP (Directors' Remuneration Report Regulations - DRRR, August 1, 2002), mandating its adoption by firms listed on the London Stock Exchange. Many other countries subsequently followed the UK's lead.

This article examines the consequences of introducing SoP in Canada. The Canadian context is interesting because, unlike in many other countries (United Kingdom, United States, Switzerland, and the Netherlands), SoP is not prescribed by regulation in Canada. In other words, the board of each of the TSX-listed firms made a conscious decision to consult shareholders about compensation policies. Economic players therefore question the relevance of a regulation that would compel all companies on the Canadian market to adopt SoP (Mangen \& Magnan, 2012; Institute for governance of public and private organizations, 2010; Mercer, 2014). Some institutional investors, like the Ontario Teachers' Pension Plan, believe that the cost of an SoP regulation would exceed the anticipated benefits (lower agency costs).

To contribute to this debate, this study aims to measure the impact of SoP on the compensation of Canadian 
corporate executives and to determine whether a shareholder vote reduces executive total compensation. It also examines whether the advisory vote improves the pay-performance relationship.

This article first presents a literature review, followed by a discussion of the data collection and the results.

\section{Literature Review}

Academic literature on CEO compensation primarily addresses its determinants and its incentive impact on executive behaviour. In the process of creating shareholder value, the method of compensation is a key factor in the alignment of CEO and shareholder interests (Jensen \& Meckling, 1976, Schleifer \& Vishny, 1997). From this perspective, CEO compensation should be tied to organizational performance to justify its dollar amount.

One of the first trends noted in the literature is the rising level of executive pay in general. A sixfold increase in top executives' salaries in the US over a period of more than 20 years (1980-2003) is linked to globalization, greater risk and firm size (Gabaix \& Landier, 2008). Over a period of 35 years (1971-2008), the rise in executive compensation in Canada has been closely related to the amount of information made available to members of the board (Gélinas \& Baillargeon, 2013). This trend intensified as of 1994, the year in which information on executive pay was made publicly available (Craighead et al., 2004). From 1998 to 2012, the salaries of executives of firms listed on the Toronto Stock Exchange rose by 73\% (Mackenzie, 2012).

In more general terms, growing regulatory requirements respecting information disclosure in all countries appear to have led to standardized practices. In response, the most talented executives use these practices to negotiate above-standard pay packages, which in turn has lead to escalating compensation (Belot \& Ginglinger, 2013; St-Onge \& Magnan, 2008). Above and beyond these compensation levels, the issue of how salaries are structured (i.e., the method of payment rather than the amount) needs to be examined (Jensen \& Murphy, 1990). Compensation is structured around a fixed and a variable component, the latter being tied to performance (bonus, stock options). Studies on pay-performance linkage most often conclude this connection is weak (Murphy, 1985; Jensen \& Murphy, 1990; Core, Guay, \& Larcker, 2003; Leone, Wu, \& Zmmerman, 2006). However, longer-term studies show an improvement in the compensation-performance relationship (Frydman \& Saks, 2010; Kaplan \& Rauth, 2010). A weak link between these two elements raises questions about the effectiveness of boards' oversight of CEOs (Bebchuk \& Fried, 2003, 2005; Walsh, 2009). In such instances, managerial power derives from the lack of independence of board members and results in sub-optimal performance (Brick, Palmon, \& Wald, 2006).

To combat compensation escalation and overly passive boards, the decade from 2000 to 2010 was marked by growing shareholder influence (Thomas et al., 2012). SoP enables shareholders to vote on executive pay and appears to be the goal of a movement towards institutionalization (Pagnattaro \& Greene, 2011). In some countries, such as the United Kingdom, Australia, the United States, Germany, and France, this control mechanism is in the form of an advisory vote. In others, it is in the form of a vote disapproving the board's policy that compels directors to take shareholders' viewpoints into account and amend the board's compensation policy accordingly (the Netherlands, Sweden, Switzerland and United Kingdom since 2012). Given the relatively recent introduction of this control mechanism, few convincing studies measuring its impact have as yet been conducted. Those studies that have been carried out focus primarily on the British and American markets.

As mentioned in the introduction, the British government was the first to implement SoP regulations, mandating its adoption by firms listed on the London Stock Exchange (DRRR, 2002). These regulations require that a report explaining and justifying the compensation policy be submitted to a shareholder advisory vote. This measure was reinforced by a provision on information disclosure in 2012, when a binding shareholder vote to be conducted every three years was introduced. From 2002 to 2007, it was noted that less than $10 \%$ of shareholders voted against their board's proposal (Conyon \& Sadler, 2010). SoP regulation appears to encourage businesses with the most controversial practices to improve their executives' pay-performance sensitivity (Ferri \& Maber, 2013).

Prior to the introduction of the regulation in the United States, companies were subject to pressure in the form of shareholder resolutions advocating more effective monitoring of compensation policies. From 1997 to 2007, Ertimur, Ferri and Muslu (2011) observed a reduction in extreme compensation subsequent to shareholders' pressure reinforcing their authority. When examining shareholder resolutions on compensation from 2006 to 2008, Burns and Minnick (2013) noted no change in the total compensation paid. However, they did see a change in compensation structure overall, with bonuses declining in favour of increased distribution of stock options.

Under the Dodd-Frank Act, American listed firms are required to submit a report on executive compensation to a 
shareholder vote. A separate shareholder resolution determines whether the vote is to occur once a year, every two years, etc. The Act also provides for an advisory vote on golden parachute payments (Tchotourian, 2009 and 2010). Stock market reaction to the Act was positive (Cai \& Walkling, 2011) since shareholders perceived SoP as creating wealth and expected agency conflicts to decrease. Furthermore, a year after the Act was adopted, it was noted that $71 \%$ of firms received over $90 \%$ shareholder support, $23 \%$ enjoyed $70 \%$ to $90 \%$ support, while only $6 \%$ received from $50 \%$ to $70 \%$ (Thomas et al., 2012). As well, shareholders generally approved the compensation plans proposed by boards (Conyon, 2013). To avoid negative shareholder votes, boards provided explanations supporting their position, thereby improving dialogue with institutional investors (Deane, 2007; Ferri \& Maber, 2013).

Given that the aim of SoP is to combat excessive compensation when boards are dominated by powerful CEOs and/or process information deficienthly (Mangen \& Magnan, 2012), we have developed the following two hypotheses to examine the Canadian context where the adoption of SoP remains voluntary. According Cai and Walkling (2011) and Grundfest (1993), SoP is symbolic, and symbols can lead to negative publicity and embarrassment. Thus, to prevent the embarrassment that could ensue from a low approval vote on executive compensation, management may be more willing to accept the concerns of directors representing the shareholders (Cai \& Walkling, 2011). In this case, directors' concerns would be reflected by limiting executive compensation and a closer pay-performance connection, which gives rise to the following hypotheses:

$\mathrm{H}_{1}$ : The advisory vote reduces executive total compensation.

$\mathrm{H}_{2}$ : The advisory vote improves pay-performance sensitivity.

These hypotheses are tested empirically based on a sample of 45 firms listed on the Toronto Stock Exchange that voluntarily adopted SoP.

\section{Data Collection Methodology and Sample}

Firms that voluntarily adopted SoP were identified through publications of the Shareholder Association for Research and Education (SHARE.ca), an organization that encourages and assists institutional investors to maximize long-term financial returns by promoting good corporate governance, respect for human rights, vibrant communities and a healthy environment. It lists shareholder activist proposals targeting Canadian companies as well as provides information on the adoption of the advisory vote by Canadian firms. In all, 96 listed firms were identified. The firms selected implemented SoP as early as 2010 and as late as 2012 . Twenty-eight firms were eliminated from the list because information on CEO compensation was not available for the three years before and after the adoption of SoP. Twenty-three other firms were eliminated because of a change of CEO during the same observation period. The final sample was thus comprised of 45 firms.

CEO compensation data were collected manually from official documents submitted to the Canadian Securities Administrators (www.sedar.com) for the three years before and three years after SoP implementation. The accounting and financial data were derived from the Research Insight database. The following accounting and financial measures for each firm were added to the Research Insight data: return on assets, return on equity, total assets, total equity, share price at the beginning and at the end of the year, total common shares, retained earnings and contributed surplus.

The first analyses compared the mean salary variations before and after the implementation of SoP. In other words, we tested:

$$
\mathrm{H}_{0}: \mu_{\text {Salary variations before }}-\mu_{\text {Salary variations after }}=0
$$

This test enabled us to determine whether CEO salaries grew at the same pace before and after SoP implementation. We also performed this test on return on assets, return on equity, return on shares, salary/total assets ratio and, lastly, salary/total equities ratio, in order to relate salary growth to the other financial performance variables.

We then carried out multiple linear regressions to examine whether there was a link between CEO compensation and the firms' various financial performance measures for the three years before and after the adoption of the advisory vote. These financial variables were: (1) return on assets (ROA), (2) return on equity (ROE), and (3) return on shares (RETURN). The regression models also included total assets (ASSET) in order to control for the impact of firm size on CEO compensation. The following four multiple linear regressions were used:

$$
\begin{aligned}
& \text { ROA }_{\text {Before}}, R_{\text {RTURN }} \text { Before, } \\
& \text { ROE }_{\text {Before }}, \text { RETURN } \\
& \text { Before, }
\end{aligned}
$$




$$
\mathrm{ROE}_{\text {After, }} \text { RETURN } \text { After, } \ln (\mathrm{ASSETS})_{\text {After }} \rightarrow \ln (\mathrm{COMP})_{\text {After }}
$$

A logarithmic transformation was used to measure the total assets (ASSETS) and salary (COMP) variables because of the nature of their distribution.

\section{Results}

Table 1 sets out the names of the firms included in the sample and the date they voluntarily adopted the advisory vote.

Table 1. Sample of firms that adopted the advisory vote

\begin{tabular}{|c|c|}
\hline Names & Date of adoption \\
\hline Agnico-Eagle Mines Ltd. & 30 April 2010 \\
\hline Agrium Inc. & 10 May 2011 \\
\hline Aimia Inc. & 12 May 2010 \\
\hline Air Canada & 8 April 2011 \\
\hline ARC Resources Ltd. & 18 May 2010 \\
\hline Atlantic Power Corporation & 29 June 2010 \\
\hline Bank of Montreal & 3 March 2009 \\
\hline Bank of Nova Scotia & 3 March 2009 \\
\hline Bombardier Inc. & 1 June 2010 \\
\hline Canadian Imperial Bank of Commerce & 26 February 2009 \\
\hline Canadian Natural Resources Ltd. & 5 May 2011 \\
\hline Canadian Western Bank & 4 March 2010 \\
\hline Celestica Inc. & 1 October 2011 \\
\hline Empire Company Ltd. & 11 September 2009 \\
\hline Enbridge Inc. & 11 May 2010 \\
\hline Finning International Inc. & 13 May 2010 \\
\hline First Quantum Minerals & 14 May 2009 \\
\hline Golden Star Resources Ltd. & 6 May 2010 \\
\hline Imax Corporation & 9 June 2010 \\
\hline Industrial Alliance Insurance and Financial Service & 6 May 2009 \\
\hline Just Energy Group Inc. & 29 June 2010 \\
\hline Laurentian Bank & 16 March 2009 \\
\hline MacDonald, Dettwiler and Associates Ltd. & 5 May 2010 \\
\hline Major Drilling Group International Inc. & 9 September 2010 \\
\hline Manitoba Telecom Services Inc. & 4 May 2011 \\
\hline Maple Leaf Foods Inc. & 29 April 2010 \\
\hline MDC Partners Inc. & 1 June 2010 \\
\hline Methanex Corporation & 29 April 2010 \\
\hline National Bank & 27 February 2009 \\
\hline North West Company Inc. & 14 June 2010 \\
\hline Pan American Silver Corporation & 12 May 2009 \\
\hline Potash Corporation & 7 May 2009 \\
\hline Precision Drilling Corporation & 11 May 2010 \\
\hline Premium Brands Holdings Corporation & 4 May 2010 \\
\hline QLT Inc. & 26 May 2010 \\
\hline Royal Bank of Canada & 3 March 2009 \\
\hline Russel Metals Inc. & 12 May 2009 \\
\hline Stantec Inc. & 12 May 2011 \\
\hline Suncor Energy Inc. & 4 May 2010 \\
\hline Talisman Energy Inc. & 5 May 2010 \\
\hline TD Bank & 25 March 2009 \\
\hline Teck Resources Ltd. & 22 April 2010 \\
\hline TELUS Corporation & 7 May 2009 \\
\hline Thompson Creek Metals Company Inc. & 6 May 2010 \\
\hline Yamana Gold Inc. & 4 May 2011 \\
\hline
\end{tabular}


Table 2 shows the activity sectors represented by the firms making up the sample. As can be seen, a number of sectors are represented. The manufacturing, financial, and mines and metals sectors respectively represent $22 \%$, $20 \%$ and $17.78 \%$ of the firms included in the sample.

Table 2. Activity sectors

\begin{tabular}{lc}
\hline Activity sector & Percentage of firms \\
\hline Manufacturing & $22.00 \%$ (10 firms) \\
Financial & $20.00 \%$ (9 firms) \\
Mining and metals & $17.78 \%$ ( 8 firms $)$ \\
Retail stores & $11.11 \%$ (5 firms) \\
Services & $11.11 \%$ (5 firms) \\
Telecommunication and public services & $8.89 \%$ (4 firms) \\
Oil and gas & $8.89 \%$ (4 firms) \\
Total & $100.00 \%$ (45 firms) \\
\hline
\end{tabular}

Table 3 presents the descriptive statistics of the different variables before and after the adoption of SoP. The $t$ tests carried out on the differences in variation in CEO compensation before and after the adoption of SoP are not significant. The same analyses were also performed on the variations in ROA, ROE and share return (RETURN), with no significant result.

Table 3. Descriptive statistics $(\mathrm{N}=45)$

\begin{tabular}{|c|c|c|c|}
\hline Variables & Mean & SD & Median \\
\hline$\Delta$ CEO Compensation before & $13.69 \%$ & $23.82 \%$ & $3.78 \%$ \\
\hline$\Delta \mathrm{CEO}$ Compensation after & $18.46 \%$ & $28.27 \%$ & $12.05 \%$ \\
\hline$\triangle \mathrm{ROA}$ before & $6.46 \%$ & $352.66 \%$ & $-19.87 \%$ \\
\hline$\triangle \mathrm{ROA}$ after & $67.68 \%$ & $710.68 \%$ & $8.91 \%$ \\
\hline$\Delta$ ROE before $(\mathrm{N}=41)$ & $54.79 \%$ & $449.75 \%$ & $-12.31 \%$ \\
\hline$\Delta \mathrm{ROE}$ after $(\mathrm{N}=41)$ & $82.11 \%$ & $753.87 \%$ & $5.29 \%$ \\
\hline$\triangle$ RETURN before & $393.33 \%$ & $4032.36 \%$ & $-170.41 \%$ \\
\hline$\triangle$ RETURN after & $-212.44 \%$ & $434.85 \%$ & $-150.39 \%$ \\
\hline$\Delta$ Compensation/Assets before & $11.90 \%$ & $35.71 \%$ & $2.05 \%$ \\
\hline$\Delta$ Compensation/Assets after & $11.76 \%$ & $29.71 \%$ & $6.40 \%$ \\
\hline$\Delta$ Compensation/Shareholders' equity before & $-6.31 \%$ & $85.95 \%$ & $-1.78 \%$ \\
\hline$\Delta$ Compensation/Shareholders' equity after & $26.71 \%$ & $136.94 \%$ & $2.41 \%$ \\
\hline
\end{tabular}

We can conclude that the adoption of SoP seems to have little impact on Canadian CEO compensation amounts. The salary of the CEO of each of the 45 firms in the sample continued to grow at the same pace after the adoption of the advisory vote. 
Table 4. Results of the multiple linear regressions

\begin{tabular}{|c|c|c|c|c|}
\hline Independent variables & LnCOMP $_{\text {before }}$ & $\operatorname{LnCOMP}_{\text {after }}$ & LnCOMP $_{\text {before }}$ & LnCOMP $_{\text {after }}$ \\
\hline ROA & 0.001 & 0.004 & & \\
\hline ROE & & & 0.002 & 0.002 \\
\hline RETURN & 0.061 & -0.089 & 0.039 & -0.207 \\
\hline LnASSETS & $0.254 * *$ & $0.229 * *$ & $0.284 * *$ & $0.267 * *$ \\
\hline Intercept & $9.314^{* *}$ & $10.055^{* *}$ & $8.583 * *$ & $9.107 * *$ \\
\hline $\mathrm{R}$ & 0.625 & 0.572 & 0.677 & 0.681 \\
\hline $\mathrm{R}^{2}$ & 0.390 & 0.327 & 0.458 & 0.464 \\
\hline Adjusted $\mathrm{R}^{2}$ & 0.376 & 0.311 & 0.444 & 0.541 \\
\hline F-value & $27.939 * *$ & $21.194 * *$ & $33.519 * *$ & $34.377 * *$ \\
\hline No. of observations & 135 & 135 & 135 & 135 \\
\hline
\end{tabular}

** $\mathrm{p}<0.001$ one-tailed test when the sign is predicted, and two-tailed otherwise.

As Table 4 illustrates, the explanatory thresholds of the variance (adjusted $\mathrm{R}^{2}$ ) are between 0.376 and 0.311 before the adoption of SoP and 0.444 and 0.541 after its adoption, signaling an improvement in the explanatory thresholds after the adoption of SoP. However, the only significant coefficients associated with the independent variables are those relating to total assets (LnASSETS), which is a control variable. The accounting and financial performance variables do not appear to be linked to CEO compensation before or after the adoption of SoP. It can therefore be concluded that SoP adoption had no impact on the relationship between accounting and financial performance measures and executive compensation.

\section{Conclusion}

The results of the analyses tend to show that SoP has little impact on Canadian CEOs' compensation, in terms of either growth or linkage to financial performance. These findings provide empirical observations to answer questions about the potential contribution of this new governance tool already in use in a number of countries. They also raise questions about the contribution of SoP in relation to the cost of its implementation, particularly in a regulatory context as is the case in the United Kingdom and the United States. According to the first observations analyzed in this study, the costs firms incur to implement SoP do not appear to be offset by a reduction in compensation amount or an improved pay-performance relationship. Other complementary options, such as the publication of the equity ratio-which reflects the relationship of the CEO's salary to the average salary of the employees (Champoux-Paillé, 2010)-could possibly be preferable (with or without SoP). This user-friendly ratio could put into perspective the size of the CEO's pay and its growth in relation to the growth of employees' average pay. Such information could help more effectively define CEO compensation during the SoP process at the AGM.

This study has certain limitations, one of which is the relatively small size of the sample. In the long term, if SoP continues to be institutionalized in Canada, and this appears to be the case, the number of observations will increase, enabling the use of other types of analyses, which could, for instance, take firms' governance practices and specific features into account. The period of observation could also be extended; over time, shareholders might gain more understanding of SoP, which would in turn influence its use. A longer application period would enable analyses that could identify trends and practices in SoP application. In addition, certain variables potentially tied to CEO compensation may not have been included in the analyses, despite a fairly meticulous reading of the description of the CEO compensation plans provided in the sample firms' official documentation.

This study opens up various avenues of research. With a larger sample of observations, it could be interesting to examine the percentage of votes supporting CEO compensation plans rather than the vote itself. The influence of SoP may be more evident in firms where CEO compensation plans receive little support during the SoP procedure. The impact of SoP on CEO compensation could also be examined in light of directors' specific characteristics. The level of their compensation and whether it is tied to financial performance could also be topics of interest. 


\section{References}

Bebchuk, L. A., \& Fried, J. M. (2003). Executive Compensation as an Agency Problem. The Journal of Economic Perspectives, 17(3), 71-92. http://dx.doi.org/10.3386/w9813

Bebchuk, L. A., \& Fried, J. M. (2005). Pay without Performance: Overview of the Issues. Journal of Applied Corporate Finance, 17(4), 8-23. http://dx.doi.org/10.1111/j.1745-6622.2005.00056.x

Belot, F., \& Ginglinger, E. (2013). Rendre compte de la rémunération des dirigeants, qu'attendre du say on pay? Revue Française de Gestion, 237, 57-71. http://dx.doi.org/10.3166/RFG.237.57-71

Brick, I. E., Palmon, O., \& Wald, K. J. (2006). CEO Compensation, Director Compensation, and Firm Performance: Evidence of Cronyism. Journal of Corporate Finance, 12(3), 403-423. http://dx.doi.org/10.1016/j.jcorpfin.2005.08.005

Burns, N., \& Minnick, K. (2013). Does Say-on-Pay Matter? Evidence from Say-on Pay Proposals in the United States. The Financial Review, 48, 233-258. http://dx.doi.org/10.1111/fire.12002

Cai, J., \& Walkling, R. A. (2011). Shareholders' Say on Pay: Does it Create Value? Journal of Financial and Quantitative Analysis, 46(2), 299-339. http://dx.doi.org/10.1017/S0022109010000803

Champoux-Paillé, L. (2010). Médac-Rémunérer la direction, ratio d'équité interne et vote consultatif sur la politique de rémunération (mai). Retrieved from http://www.giref.uqam.ca/pdf/Etude-Louise\%20C.-Paille-Pol.remuneration.pdf

Conyon, M. (2013). Executive Compensation and Board Governance in US Firms. The Economic Journal. http://dx.doi.org/10.1111/ecoj.12120

Conyon, M., \& Sadler, G. (2010). Shareholder Voting and Directors Remuneration Report Legislation: Say on Pay in the UK. Corporate Governance: An International Review, 18(4), 356-383. http://dx.doi.org/10.1111/j.1467-8683.2010.00802.x

Core, J., Guay, W. R., \& Larcker, D. F. (2003). Executive Equity Compensation and Incentives: A Survey. Economic Policy Review, 9(1), 27-50.

Craighead, J., Magnan M. L., \& Thorne, L. (2004). The Impact of Mandated Disclosure on Performance-Based CEO Compensation. Contemporary Accounting Research, 21(2), 369-398. http://dx.doi.org/10.1506/BPCX-D3FC-Y8VY-M541

Deane, S. (2007). Say on Pay: Results from Overseas. The Corporate Board, 28(165), 11-18.

Ertimur, Y., Ferri, F., \& Muslu, V. (2011). Shareholder Activism and CEO Pay. Review of Financial Studies, 24(2), 535-592. http://dx.doi.org/10.1093/rfs/hhq113

Ferri, F., \& Maber, D. A. (2013). Say on Pay Vote and CEO Compensation: Evidence from the UK. Review of Finance, 17(2), 527-563. http://dx.doi.org/10.1093/rof/rfs003

Frydman, C., \& Saks, R. (2010). Executive Compensation: A New View from a Long Term Perspective. The Review of Financial Studies, 23(5), 2099-2138. http://dx.doi.org/10.1093/rfs/hhp120

Gabaix, X., \& Landier, A. (2008). Why has CEO Pay Increased so Much? Quarterly Journal of Economics, 123(1), 49-100. http://dx.doi.org/10.3386/w12365

Gélinas, P., \& Baillargeon, L. (2013). CEO Compensation in Canada 1971-2008. International Journal of Business and Management, 8(12), 1-7. http://dx.doi.org/10.5539/ijbm.v8n12p1

Grundfest, J. A. (1993). Just Vote No: A Minimalist Strategy for Dealing with Barbarians inside the Gates. Stanford Law Review, 857-937.

Institute for governance of public and private organizations. (2010). Policy paper No. 5: Le vote consultatif sur la rémunération des dirigeants (Say on Pay) - Un pas en avant vers une meilleure gouvernance? HEC Montréal and John Molson School of Business.

Jensen, M. C., \& Meckling, W. (1976). Theory of the Firm: Managerial Behavior, Agency Costs and Capital $\begin{array}{llll}\text { Structure. Journal of Financial 305-360. } & \text { Economics, }\end{array}$ http://dx.doi.org/10.1016/0304-405X(76)90026-X

Jensen, M. C., \& Murphy, K. J. (1990). Performance Pay and Top Management Incentives. The Journal of Political Economy, 98(2), 225-264. http://dx.doi.org/10.1086/261677 
Kaplan, S., \& Rauth, J. (2010). Wall Street and Main Street: What Contributes to the Rise in the Highest Incomes. The Review of Financial Studies, 23(3), 1004-1050. http://dx.doi.org/10.1093/rfs/hhp006

Leone, A., Wu, J., \& Zimmerman, J. (2006). Asymmetric Sensitivity of CEO Cash Compensation to Stock Returns. Journal of Accounting and Economics, 42(1-2), 167-192. http://dx.doi.org/10.1016/j.jacceco.2006.04.001

Mackenzie, H. (2012). Canada CEO Elite 100: The 0.01\%. Canadian Centre for Policy Alternatives.

Mangen, C., \& Magnan, M. (2012). Say on Pay: A Wolf in Sheep's Clothing? Academy of Management Perspectives, 26(2), 86-104. http://dx.doi.org/10.5465/amp.2010.0098

Mercer. (2014). Perspectives-Rémunération de la haute direction-Pour le meilleur et pour le pire: le vote consultatif sur la rémunération des dirigeants s'établit au Canada. Retrieved from http://www.mercer.ca/content/dam/mercer/attachments/north-america/canada/Perspectives-Remuneration_d e_la_haute_direction-Janvier_2014.pdf

Murphy, K. (1985). Corporate Performance and Managerial Remuneration: An Empirical Analysis. Journal of Accounting and Economics, 7(1-3), 11-42. http://dx.doi.org/10.1016/0165-4101(85)90026-6

Pagnattaro, M. A., \& Greene, S. (2011). 'Say on Pay': The Movement to Reform Executive Compensation in the United States and European Union. Northwestern Journal of International Law \& Business, 31(Summer), 591-634.

Schleifer, A., \& Vishny, R. W. (1997). A Survey of Corporate Governance. Journal of Finance, 52(2), 737-783.

St-Onge, S., \& Magnan, M. (2008). La rémunération des dirigeants: Mythes et recommandations. Gestion, 33(3), $25-40$.

Tchotourian, I. (2009). Eclairage. H.R. 3269: La réaction des parlementaires américains en matière de rémunération des dirigeants. Bulletin Joly Bourse, 11, 950.

Tchotourian, I. (2010). Eclairage. Gouvernance d'entreprise et rémunération à l'aube de la nouvelle régulation financière américaine. Bulletin Joly Bourse, 5, 376.

Thomas, R. S., Palmiter, A. R., \& Cotter, J. F. (2012). Dodd-Frank's Say-on-Pay: Will it Lead to a Greater Role for Shareholders in Corporate Governance. Cornell Law Review, 97(5), 1213-1266.

Walsh, J. P. (2009). Are U.S. CEOs overpaid? A Partial Response to Kaplan. Academy of Management Perspectives, 23(3), 33-41. http://dx.doi.org/10.5465/AMP.2009.37008004

\section{Copyrights}

Copyright for this article is retained by the author(s), with first publication rights granted to the journal.

This is an open-access article distributed under the terms and conditions of the Creative Commons Attribution license (http://creativecommons.org/licenses/by/3.0/). 